\title{
超音波による有機塩素化合物の分解
}

\author{
趙 一先 ${ }^{1)}$, 張 大年 ${ }^{1)}$, 稲津 晃司 ${ }^{2)}$, 永田 良雄 ${ }^{3)}$, \\ 竹中 規訓 ${ }^{4)}$, 坂東 博 ${ }^{4)}$, 前田 泰昭 ${ }^{4)}$ \\ ${ }^{1)}$ 中国華東理工大学環境工程研究所 (中国上海市梅隴路130号) \\ ${ }^{2)}$ 東京工業大学資源化学研究所（干 226-0026 神奈川県横浜市緑区長津田町4259） \\ ${ }^{3)}$ 大阪府立大学先端科学研究所（ $\bar{T} 599-8531$ 大阪府堺市学園町 1-1) \\ ${ }^{4)}$ 大阪府立大学工学部（テ599-8531 大阪府堺市学園町1-1)
}

[平成11年 5 月 6 日受理］

\section{Decomposition of Chlorinated Hydrocarbons in Aqueous Solutions by Ultrasonic Irradiation}

\author{
Yi-Xian $Z \mathrm{HAO}^{1)}$, Da-Nian $Z \mathrm{ZHANG}^{1)}$, Koji INAZU ${ }^{2)}$, Yoshio NAGATA ${ }^{3)}$, \\ Norimichi TAKENAKA ${ }^{4}$, Hiroshi BANDOW ${ }^{4)}$ and Yasuaki MAEDA ${ }^{4)}$ \\ ${ }^{1)}$ Institute of Environmental Engineering, East China University of Science \& Technology \\ (130 Meilong Road, Shanghai 200237 P.R.China) \\ ${ }^{2)}$ Research Laboratory of Resources Utilization, Tokyo Institute of Technology \\ (4259 Nagatsuda, Midori-ku, Yokohama, Kanagawa 226-0026) \\ ${ }^{3}$ Research Institute for Advanced Science and Technology, Osaka Prefecture University \\ (1-1 Gakuen-cho, Sakai, Osaka 599-8531) \\ ${ }^{4)}$ College of Engineering, Osaka Prefecture University \\ (1-1 Gakuen-cho, Sakai, Osaka 599-8531)
}

[Received May 6, 1999]

\section{Summary}

The decomposition of dilute chlorinated hydrocarbons, such as carbon tetrachloride, chlorobenezes, chlorophenoles and chloroacetaldehydes, in aqueous solution by high intensity ultrasonic irradiation were investigated. Besides chloroacetaldehydes, more than $85 \%$ of their initial amounts are rapidly decomposed in less than 1 hour. The major products were chloride anion, carbon monoxide, carbon dioxide and hydrogen. This reaction rate was accelerated under argon atmosphere. The sonolytical reactivity of these chlorinated hydrocarbons are influenced by their solubility in water and their volatility from water.

Key words: Ultrasonic Irradiation, Chlorinated Hydrocarbons, Ultrasonic Degradation, Wastewater Treatment 


\section{1. はじめに}

有機塩素化合物は優れた性質をもつことから，多くの 産業用用途がある。PCB はトランスなどに, DDT も農 薬, 殺虫剤として用いられて来たが, 現在では使用も生 産もされていない。さらに, トリクロロエチレン, パー クロルエチレンなどが洗浄用溶戍として大量に用いられ ている。また, 浄水の塩素処理過程で生成するトリハロ メタンも数多く存在する ${ }^{1)}$ 。これらの有機塩素化合物は 人体を含めたあらゆる自然界の動植物から検出されてい る ${ }^{2)}$ 。しかも, 有機塩素化合物には難分解性, 毒性, 発 癌性をもつものが多いので, 効率の良い処理方法の開発 が待たれている。

有害物質の処理には曝気などによる揮散法，活性炭な どによる吸着法が実用化されている ${ }^{3)}$ 。しかし，これら の方法で回収をするにしても回収率が $30 \%$ 程度に留まっ ている4)。さらに, これらは非分解法であるために, 有 機塩素化合物による環境污染問題の根本的な解決法とは 成りえない。近年, オゾン酸化 ${ }^{5)}$, 湿式酸化 ${ }^{6}$ など酸化 還元法, 酸化チタンなどの光触媒 ${ }^{7)}$, 超音波処理 ${ }^{8)}$ につ いて様々な研究が行われるようになった。

本研究では, 水への高出力超音波照射によって塩素化 脂肪族炭化水素, 塩素化芳香族炭化水素, カルボニル基 をもつ有機塩素化合物の分解を行い，化合物による分解 性の違いなどの点から考察を行った。

\section{2. 実験}

\section{1 試薬}

水：イオン交換，蒸留により精製した水をさらに，ミ リポア工業社製 MILLI-Q Labo を用いて精製した超純水 を用いた。 $m$-クロロフェノール (以下 $m$ - CP と略記), モノクロロアセトアルデヒド $40 \%$ 水溶液（以下 MCAA と略記), 抱水クロラール（以下 $\mathrm{CH}$ と略記）は和光純 薬工業製試薬一級をそれぞれ用いた。四塩化炭素, クロ ロベンゼン (以下 $\mathrm{CB}$ と略記)，o-ジクロロベンゼン(以 下 $o$-DCB と略記), $m$-ジクロロベンゼン (以下 $m$-DCB と略記), $o^{-}$クロロフェノール (以下 $o^{-} \mathrm{CP}$ と略記), 炭 酸ナトリウム, 炭酸水素ナトリウム, 2-メチル-2-プロ パノール（以下 $t-\mathrm{BuOH}$ と略記）は和光純薬工業製試薬 特級をそれぞれ用いた。メタノールは和光純薬工業製高 速液体グロマトグラフ用， $n$-ヘキサンは和光純薬工業製 水質試験用, ジクロロアセトアルデヒド（以下 DCAA と略記）は Wacker Chemicals 製, ドデシルベンゼンス ルホン酸（ソフト型）は東京化成工業製を用いた。

\section{2 実験装置}

実験はFig. 1 に示す装置を用いて行った。照射容器は $\phi 50 \mathrm{~mm}$ ，底面が平らなパイレックス製のものを用いた。
恒温槽は $25 \pm 2{ }^{\circ} \mathrm{C}$, 照射位置は, 照射容器の底面を振動 子から，水中の照射した超音波波長の約半分である， $3.8 \mathrm{~mm}$ 離した。

超音波発生装置; 海上電機製（TA-4021型，200W）, 超音波発振子；海上電機製4611型 $(200 \mathrm{KHz})$, 紫外・可 視分光光度計 ; 島津製作所製 UV3100-S 型, ガスクロマ トグラフ；横河電機製 HP-5890A 型（TCD付, ECD付), イオンクロマトグラフ; 横河北辰電機製 IC-100型（ア ニオン分析用), 横河電機製 IC-7000型（有機酸分析用） を用いた。高速液体クロマトグラフ；島津製作所製 LC-6A, SPD-6A型（紫外・可視吸収検出器）を用いた。

\section{3 実験操作}

（1）試料水溶液の調製；照射容器に純水 $65 \mathrm{~g}$ を入れ, 照 射雲囲気とする気体を 60 分間バブリング後, 所定濃度の 有機塩素化合物をマイクロシリンジで注入し，攪挥後， 恒温槽に45分間放置して, 恒温にした後, 試料の濃度を GC-ECD によって確認した。DCAA は100ppm の水溶液 を $1 \ell$ の三角フラスコに調整し，それを目的の濃度に希 釈して用いた。空気雾囲気下の照射に用いる試料は, $1 \ell$ の三角フラスコに調整したものを用いた。

（2）超音波照射；照射容器に所定濃度の有機塩素化合物 水溶液を $65 \mathrm{~g}$ 入れ, $\mathrm{CCl}_{4}$ は 10 分間, $\mathrm{CB}, \mathrm{DCB}$ 類は 40 分間, $\mathrm{CP}$ 類は60分間， DCAA は 4 時間，それぞれ超音波照射 を行った。サンプリングには $\mathrm{CCl}_{4}$ の場合は 2 分, DCAA の場合は 1 時間, ほかの化合物の場合は10分ごとに $1.4 \mathrm{~m} \ell$ の試料溶液をガラス製シリンジを用いて採取し

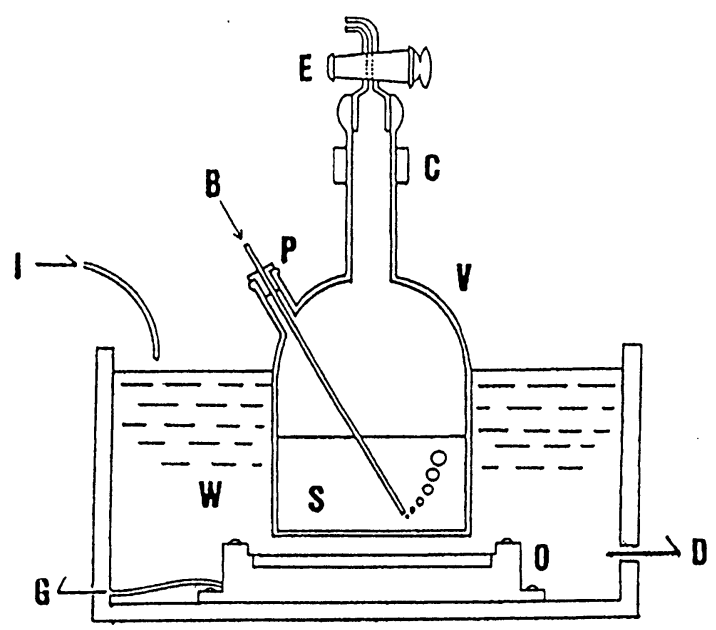

Fig. 1 Typical irradiation apparatus

$\mathrm{V}$; glass vessel, $\mathrm{S}$; sample solution, $\mathrm{O}$; oscillator, G; ultrasound generator, W; cooling water, E; cock or stopper, C; clamp, P; silicone septum, B; bubbling gas, I; cooling water inlet, $D$; cooling water drain 
た。

（3）分析方法；採取した試料溶液を $10 \mathrm{ml}$ の栓付試験管

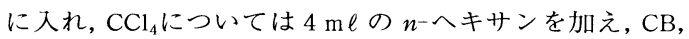
と DCB 類については $5 \mathrm{~m} \ell$ の n-ヘキサンを加え，振と うして有機塩素化合物を抽出した後, 油層の有機塩素化 合物の濃度を GC-ECD で, 水層の塩化物イオンの濃度 をイオンクロマトグラフでそれぞれ測定した。CP 類は 高速液体クロマトグラフで, DCAA は GC-ECD でそれ ぞれ定量した。同時に照射容器内の気体を有機塩素化合 物は GC-ECD で, 水素, メタン, 一酸化炭素, 二酸化 炭素は GC-TCD で測定した。

\section{3. 結果および検討}

\section{1 四塩化炭素の超音波分解}

高濃度 $(3250 \mu \mathrm{mol} / \ell)$ 四塩化炭素の空気雾囲気下で の超音波照射による分解と分解生成物の様子を Fig. 2 に 示す。図は省略するが, 低濃度 $(60 \mu \mathrm{mol} / \ell)$ の場合, 15分の超音波照射で，空気䨌囲気では $88 \%$ が，アルゴン 雲囲気では $80 \%$ が分解した。Fig. 2 に示したように，高 濃度の場合，空気雲囲気で，15分間の照射で，85\%が分 解した。アルゴンの場合の分解率は78\%であったので四 塩化炭素の超音波分解には空気雲囲気の方がアルゴン雾 囲気より分解速度が速いことが分かった。主な分解生成 物は一酸化炭素,二酸化炭素拉よび塩化物イオンであった。 他の生成物として, テトラクロロエチレンが少量とへキサ クロロエチレンが少量検出された。四塩化炭素は水の分解 により生じるOHラジカル生成速度 ${ }^{8)}(14.7 \mu \mathrm{mol} / \ell \cdot \min )$ よりも遥かに速く分解されることから，超音波照射に よって水に生成するキャビテー内で熱分解あるいは燃焼 反応により分解することが分かった。

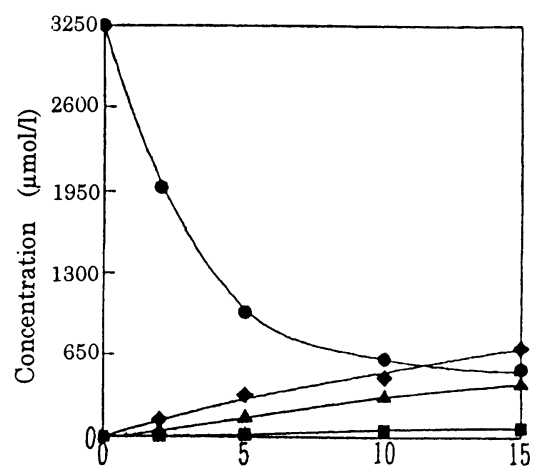

Fig. 2 Decomposition of carbon tetrachloride and formation of products during sonication of aqueous solution under air atmosphere

\section{2 クロロベンゼン類の超音波分解}

Fig. 3，4にクロロベンゼン類の超音波分解の様子を 示す。アルゴン雾囲気下, 30 分照射で $o-\mathrm{DCB}, m-\mathrm{DCB}$ は90\%以上, CB はほほ100\%分解された。図には示して いないが, $p$-DCB は水への溶解度が低いので, メチル アルコールに溶解させ，それを水に加えて超音波照射し た結果，アルゴン雲囲気下，30分照射で $90 \%$ 以上が分解 した。分解反応が $\mathrm{OH}$ ラジカルの付加によって起こるの であれば，構造の違いによって分解率の違いが認められ るはずであるが, $o-\mathrm{DCB}, m-\mathrm{DCB}, p-\mathrm{DCB} に$ 殆ど分解

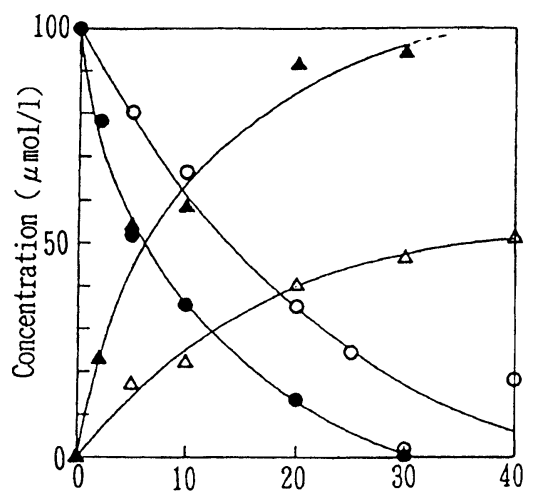

Fig. 3 Decomposition of chlorobenzene and $\mathrm{Cl}^{-}$ formation during sonication of aqueous solution

: $\mathrm{CB}, \quad \mathbf{\Delta}$ : $\mathrm{Cl}^{-}$; under argon atmosphere

$\mathrm{O}: \mathrm{CB}, \triangle \mathrm{Cl}^{-}$; under air atmosphere

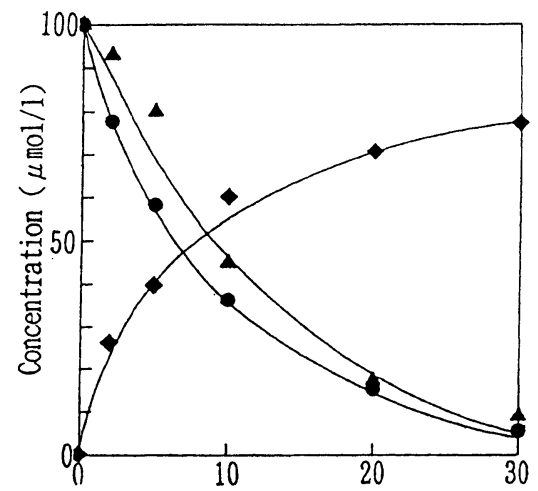

Fig. 4 Decomposition of $o^{-}, \quad m$-dichlorobenzene and $\mathrm{Cl}^{-}$formation during sonication of aqueous solution under argon atmosphere

- $m$-dichlorobenzene

A: $\sigma^{- \text {dichlorobenzene }}$

: $\mathrm{Cl}^{-}$formation of $m$-dichlorobenzene 
率の差が無い事から，分解反応の殁どが熱分解である事 が分かる。脱塩素化率は $\mathrm{CB}$ は $95 \%$ で, $o^{-}, m^{-}, p-\mathrm{DCB}$ では約 $80 \%$ であった。空気雲囲気下で CB は $85 \%$ が, DCB 類ではその $80 \%$ が分解された。また， OH ラジカル 捕捉剂である $t-\mathrm{BuOH}^{9)}$ を $\mathrm{CB}$ 水溶液濃度の 1000 倍モル量 添加しても，分解は完全には抑制されなかった（Fig. 5$)$ 。 このことから，超音波照射による $\mathrm{CB}$ の分解は, $\mathrm{OH}$ ラ ジカルなどの活性種との反応が主な分解経路ではなく, キャビテーションバブル界面領域の直接熱分解あるいは 燃焼反応も分解に大きいな役割を果たすことが分かっ た。アルゴン雲囲気下の方が処理の効率が良いのは, 空 気に比べて，アルゴンの比熱比が大きく，熱伝導度が小 さいため, キャビテーションバブル中の温度が高く, 熱 分解が起こり易いためである。

\section{3 クロロフェノール類の超音波分解}

$m$-CP のアルゴンおよび空気雾囲気下での超音波照射 による分解と塩化物イオンの生成の様子を Fig. 6 に示 す。CB と同じょうに，アルゴン雲囲気下での分解は速 く, 40分照射で $m-\mathrm{CP}$ は $100 \%$ が分解され, 脱塩素化率 は $62 \%$ であった。図は省略するが $0-\mathrm{CP}$ では $90 \%$ が分解 され，脱塩素化率は58\%であった。分解生成物として塩 化物イオン，ギ酸，酢酸，二酸化炭素が同定された。図 は省略するが, 空気の場合は, 分解率と脱塩素化率はそ れぞれ $80 \% ， 78 \%$ および45\%，30\% であった。また， $m-\mathrm{CP}$ 水溶液に $t-\mathrm{BuOH}$ を100倍モル量添加すると, 分解 は大きく抑制された（Fig. 7)。これらのことから， CB よりも親水性が高く, 蒸気圧が低いクロロフェノール類 は, $\mathrm{OH}$ ラジカルとの反応性が大きく, 主にキャビテー ションバブル周辺やバブル中で $\mathrm{OH}$ ラジカルとの反応に

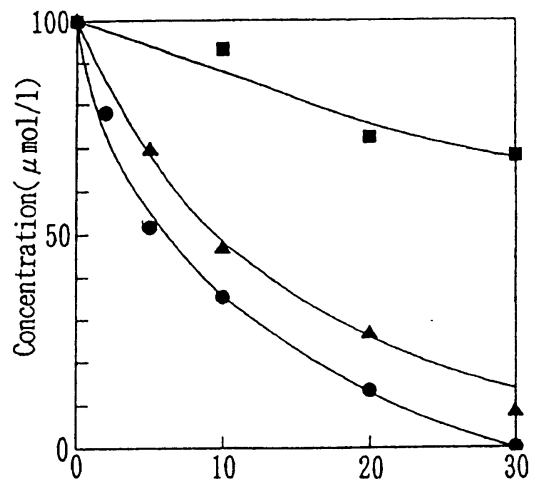

Fig. 5 Effect of $t$-butyl alcohol addition on degradation of chlorobenzene during sonication of aqueous solution under argon atmosphere

: none A: $\times 100 \mathrm{~mol}$ $\times 1000 \mathrm{~mol}$
よって分解すると考えられた。

\section{4 クロロアセトアルデヒド類の超音波分解}

Fig. 8 にMCAA, DCAA, CH のアルゴン, 空気の各 雲囲気下での超音波分解の様子を示す。やはりアルゴン 雾囲気下で分解が促進された。しかし, 分解速度が遅く, 4 時間照射で，やっとその $80 \%$ 以上が分解された。Fig. 9 にDCAAの脱塩素化, 無機炭素転化を示した。DCAA の分解量と塩化物イオンの生成量 (DCAA からは 2 分子 の塩化物イオンが生成する) が大きく異ならない事から 脱塩素はほほ定量的に起こると考えられる。しかし一酸

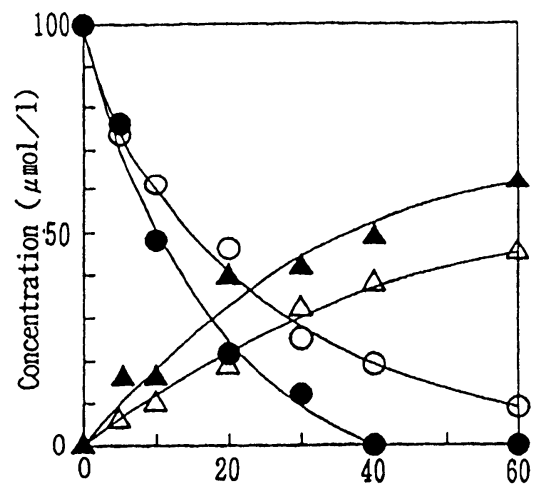

Fig. 6 Decomposition of $m$-chlorophenol and $\mathrm{Cl}^{-}$ formation during sonication of aqueous solution

- $\mathrm{m}-\mathrm{CP} \quad \mathbf{\Delta}: \mathrm{Cl}$; under argon atmosphere

$\mathrm{O}: \mathrm{m}-\mathrm{CP} \quad \triangle \mathrm{Cl}$; under air atmosphere

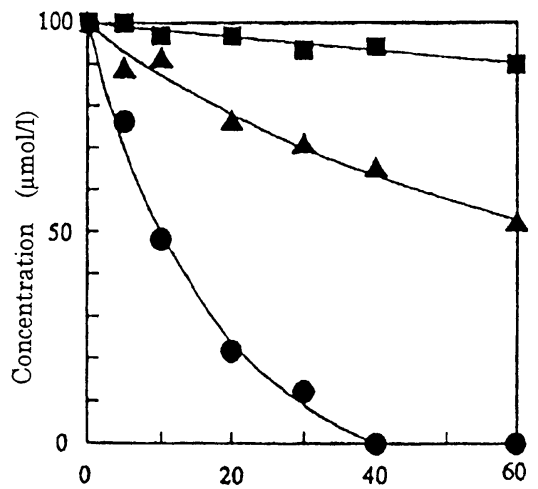

Fig. 7 Effect of $t$-butyl alcohol addition on degradation of $m$-chlorophenol during sonication of aqueous solution under argon atmosphere

: none $\mathbf{A}: \times 10 \mathrm{~mol}$

$\times 100 \mathrm{~mol}$ 
化炭素の生成量は DCAA の分解量の半分ほどにしかな らず, 副生成物の存在が示唆されるが, 定性, 定量とも できなかった。今後 GC-MSを用いてさらに詳しい分析 が必要である。図は省略したが, MCAAでも同様の,結 果を得た。分解速度は $\mathrm{MCAA}>\mathrm{DCAA}>\mathrm{CH}$ の順で, 反 応分子中の塩素原子数か増加するに従って分解速度は減 少した。また，水への超音波照射による過酸化水素の生 成量 $(\mathrm{OH}$ ラジカル生成速度の半分 $14.7 / 2=7.4 \mu \mathrm{mol} / \ell)$ は MCAA と DCAA を加えても，それぞれ7.4 $\mu \mathrm{mol} / \ell$ お よび7.3 $\mu \mathrm{mol} / \ell$ とほほ同じであった。この結果, 水への 超音波照射によって生成した $\mathrm{OH}$ ラジカルのほとんど が，MCAA，DCAA と反応できずに再結合して過酸化水 素を生成したものと考えられた。これらの結果から分解 反応はキャビテーション近傍の熱分解によって進行する

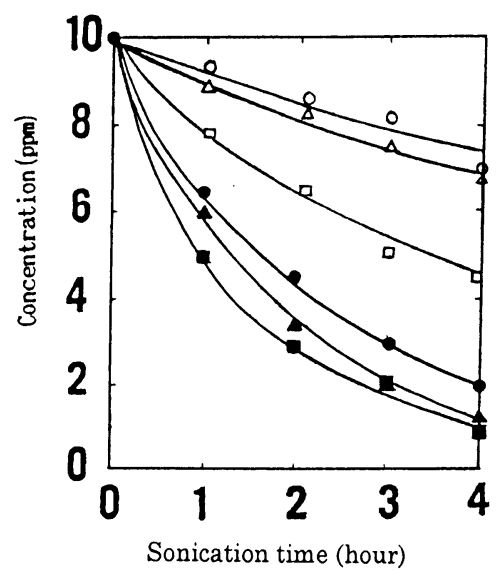

Fig. 8 Decomposition of chloroacetaldehydes in the during sonication of aqueous solution under various atmosphere

口: MCAA $\boldsymbol{\Delta}$ : DCAA

: $\mathrm{CH}$; under argon atmosphere

$\square$ : MCAA $\triangle$ : DCAA

$\mathrm{O} \mathrm{CH}$; under air atmosphere
と考えられた。

\section{5 有機塩素化合物の物性と超音波分解速度}

実験で用いた有機塩素化合物の物性と超音波照射によ る初期分解速度を Table 1 に示す。分解の速さは脂肪族 塩素化合物 $>$ 芳香族塩素化合物 >カルボニル基を持つ塩 素化合物であった。疎水性と蒸気圧の大きい化合物の分 解速度は速く, 親水性で不揮発性の化合物の分解速度が 遅かった。これらのことから, 化学的な構造や性質より も溶解度や蒸気圧のほうが有機塩素化合物の超音波分解 と深い関係があると思われた。

\section{4. 結論}

超音波照射による有機塩素化合物の水溶液の分解にお いて, いずれの化合物も極めて効率良く脱塩素化が起つ た。分解の速さは, 各化合物の物性によって異なり, 化

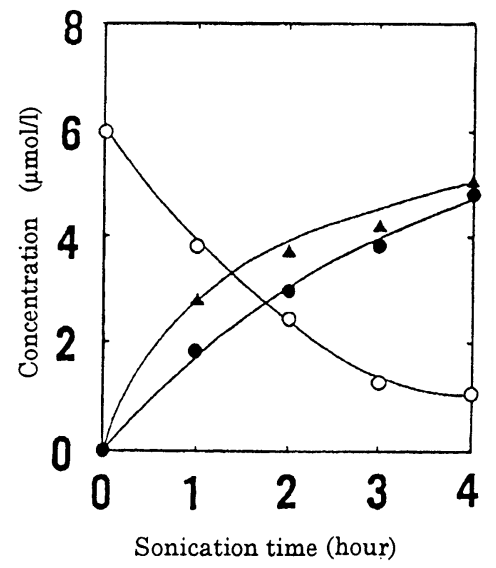

Fig. 9 Decomposition of DCAA and formation of products during sonication of aqueous solution under argon atmosphere

$\bigcirc$ : DCAA : carbon monoxide

A: chloride ion $(\times 1 / 2)$

Table 1 Properties of chlorinated compounds and rates of decomposition by sonication

\begin{tabular}{lcccccc}
\hline Compound & $\begin{array}{c}\text { Vapor } \\
\text { Pressure } \\
(\mathrm{mmHg} \rho \mathrm{C})\end{array}$ & $\begin{array}{c}\text { Solubility } \\
\text { in Water } \\
\left(\mathrm{g} /, 20^{\circ} \mathrm{C}\right)\end{array}$ & $\begin{array}{c}\text { Boiling } \\
\text { Point } \\
\left({ }^{\circ} \mathrm{C}\right)\end{array}$ & $\begin{array}{c}\text { Concen- } \\
\text { tration } \\
(\mu \mathrm{mol} / \Omega)\end{array}$ & $\begin{array}{c}\text { Rates of Decomposition } \\
(\mu \mathrm{mol} / \mathrm{m} \cdot \mathrm{min}) \\
\text { argon }\end{array}$ \\
\hline $\mathrm{Cir}$
\end{tabular}


合物の揮発性あるいは溶解度と関係があった。疎水性と 蒸気圧の大きい化合物はキャビテイー内で迅速に熱分解 され，疎水性で蒸気圧の低い化合物はキャビテイー近傍 に集まり，界面領域での熱分解と $\mathrm{OH}$ ラジカルによって 分解する。親水性の化合物は主としてバルクの水の中で $\mathrm{OH}$ ラジカルによって分解する。これらのことから, 有 害化学物質の超音波による分解性の大小は, その蒸気圧 や水への溶解度などの物性から, ある程度予測すること ができた。

\section{謝 辞}

本研究は科学技術庁振興調整費 “協奏反応場の増幅制 御を利用した新材料創製に関する研究”の援助を受けて 行った。ここに深く感謝する。

\section{要 約}

四塩化炭素, クロロベンゼン類, クロロフェノール類, クロロアセトアルデヒド類などの有機塩素化合物水溶液 の超音波照射による分解を検討した。いずれの化合物も 短時間の照射で，80\%以上の分解が起った。主な分解生 成物は一酸化炭素, 二酸化炭素および塩化物イオンで あった。アルゴン雲囲気下で分解が促進され，分解の速 さは化合物の揮発性および水中の溶解度などの物性に よって異なり，疎水性と蒸気圧の大きい化合物は分解し 易く，親水性の化合物は分解し難くかった。分解反応は これら揮発性および水中の溶解度にとって, それぞれ キャビテーションバブル内あるいは界面領域での燃焼反

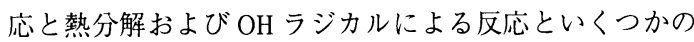

経路よって分解すると考えられた。

\section{文 献}

1) Lisk, DJ.: Enviromental Implications of Incineration of Municipal Solid Waste and Ash Disposal. Sci. Total Environ. 74, 39-66 (1988)

2）環境庁保健調査室；化学物質と環境, 392 (1988)

3）(財)大阪府緑化・環境協会；フロン等有機塩素化合物 使用実態調查報告書, 38 (1991)

4）北嶋永一, 村山 等, 小林哲也, 家合浩明：排ガス 中の溶剤回収装置を使用した金属製品製造工場にお けるトリクロロエチレンの収支, 環境化学, 1, 553-557 (1991)

5）高橋信行, 中井敏博, 加藤義重：有機化合物のオゾ ン酸化による生物分解性の変化, 水処理技術, 33, 325-335 (1992)

6）東国茂；日本化学会第63春季年会講演予講演集 I, P.801 (1982)

7) Kotronarou, C., Mills, G. and Hoffmann, M.R.: Photolysis of Chloroform and Other Organic Molecules in Aqueous $\mathrm{TiO}_{2}$ Suspensions. Environ. Sci. Technol:; 25, 494-500 (1991)

8）稲津晃司, 永田良雄, 前田泰昭: Decomposition of Chlorinatel Hydrocarbous in Aqueous Solutions by Ultrasonic Irradiation. Chem. Lett., 57-60 (1993)

9) Buttner, J., Gutierrez, M. and Henglein, A.: Sonolysis of Water-Methanol Mixtures. J. Phys. Chem., 95, 1528 (1991) 